\title{
Community intervention to improve knowledge and practices on commonly used drugs
}

\author{
Kafle KK ${ }^{1}$, Karkee SB ${ }^{1}$, Shrestha ${ }^{1}$, Prasad RR ${ }^{1}$, Bhuju GB ${ }^{1}$, Das PL $^{1}$, Chataut BD ${ }^{1}$ \\ ${ }^{1}$ International Network for Rational Use of Drugs (INRUD, Nepal)
}

\begin{abstract}
Background: World Health Organisation (WHO) estimates that about half of all medicines are inappropriately prescribed, dispensed and sold and about half of all patients fail to take their medicines properly.

Objective: The overall objective of the study was improving use of medicines in the community by creating awareness among different target groups.

Materials and methods: It was a pre-post comparison of intervention implemented at the community level in purposively selected Bhaktapur District of Kathmandu Valley, Nepal. The study was conducted in the private schools of the study district. Twelve schools were randomly selected. Thereafter, students from 6-9 grades were listed from the selected schools. Then $15 \%$ of the total students in each grade were randomly selected to get six students from each grade of the each school, totaling 288 students. The households of the selected students served as the sample households for the study. Thus, there were 288 households sampled for the study.

The intervention and the targeted intermediary groups consisted of a. training of schools teachers b. training of journalists c. interactive discussions of trained school teachers with school children using key messages and c. communication of key messages through the local F.M. radio, newspaper/ magazine.

Results: There was a significant increase in correct knowledge on action of antibiotics and excellent knowledge on the methods of administration of antibiotics of households after the intervention. Similarly, there was a significant increase in knowledge on cough as a disease and a significant decrease in the use of cough medicines after intervention. There was also a significant increase in excellent knowledge on the sources of vitamins and a significant decrease in the use of vitamin/tonics after the intervention.

Conclusion: The participation of intermediary groups eg. school teachers, journalists and school children in the implementation of intervention were successful. The groups have fulfilled the commitments in implementing the plan of action. The key messages have effectively reached the households, and the knowledge and practices of the community members in drug use have improved.
\end{abstract}

Key words: Community intervention, Use of common drugs, Knowledge and practice

$\mathrm{I}$ has been estimated by WHO that about half of all medicines are inappropriately prescribed, dispensed and sold and about half of all patients fail to take their medicines properly. Often, prescribers do not have access to unbiased information such as national formularies or standard treatment guidelines. In most cases, the consumers also do not receive necessary information from prescribers and dispensers. The information on medicines available through promotional sources are primarily aimed at advertising the use of specific product(s) and not necessarily for the health benefit of the people. Providing the right information, therefore, should be an essential part of prescribing and dispensing of medicines both in public and private sector. For improving awareness on the use of medicines at the community level the possible strategies could be - people empowerment to look after their own health more effectively and educating people and consumers extensively on a large scale ${ }^{1}$.

Community based studies from Africa, Asia and Latin America have found that up to $70 \%$ of illness episodes have been self-treated with modern medicines ${ }^{2,3}$. Public acceptance and appreciation on the role of private drug sellers on community treatment has been clearly recognised $d^{4,5,6}$.

There are studies using educational interventions aimed at different community groups such as patient,

Correspondence

Prof. Dr. K. K. Kafle

Head, Department of Clinical Pharmacology

Institute of Medicine, TUTH

E-mail: inrud@healthnet.org.np 
community members, women, women's group and mothers ${ }^{7,8,9,10,11,12,13,14}$.

In Nepal also, various educational interventions have been tested and found effective to improve use of medicines and harmful effects of irrational use of medicines at community level ${ }^{8,13,14,15}$.

\section{Materials and methods}

\section{Study Design and Sampling}

It was a pre-post comparison of intervention implemented at community level in purposively selected Bhaktapur District of Kathmandu Valley, Nepal.

\section{Selection of households}

The list of all the schools of the study district was collected from the District Education Office. From the list, the private schools of the district were identified. The total number of students in 6-9 grades (classes) of all the private schools was collected. Then on the basis of higher number of students in 6-9 grades and closeness to Arniko Highway (the highway joins Kathmandu to Tibet through Bhaktapur), the schools were listed. From this list of schools, 12 schools were randomly selected. The sampled schools were from Bhaktapur municipality, Madhyapur Thimi municipality, Balkot Village Development Committee (VDC), Dadhikot VDC, Gundu VDC and Jhaukhel VDC. Thereafter, the list of students from 6-9 grades of the selected schools was obtained. There were about 40 students in each grade. Then $15 \%$ of the total students in each grade were randomly selected to get a sample of six students from the each grade of the each school, totaling 288 students from 12 schools. The households of these selected students served as the sample for households. Thus, there were 288 households sampled for the study.

\section{Intervention and materials}

The intervention and targeted three intermediary groups consisted of

- Training of schools teachers (Medicine Awareness Training for school teachers i.e. MAT school teachers).

- Training of journalists (MAT for journalists including F.M. radio, newspaper and magazine)

- Interactive discussions of trained school teachers with school children using key messages

The schoolteachers and the journalists developed the key messages for dissemination to households through school children and the local F.M. radio, newspaper/ magazine respectively.

\section{Selection of School Teachers and Journalists}

Two teachers from each selected school were invited for the training. The teachers included either the principal or vice-principal, and science or health science teacher.

The journalists including F.M. radio and newspaper/ T.V. channel/magazine were selected for the training on the basis of findings from the baseline data of households showing their top popularity. The training also included few other journalists from media which were locally popular.

\section{Curriculum and Training Materials}

The curriculum for MAT for schools teachers included: state of drug use, significance of age and patient conditions on drug use, different dosage forms for medication, importance of proper storage and disposal, adverse impacts of some self-medicated drugs, vitamins and tonics, cough and cough preparations, and infection and antibiotics use.

The methodology of training was mainly interactive lecture except for vitamins/tonics. The methodology for training on vitamin/tonics was group activities. The group activities included identifying problems related to use of vitamins/tonics, developing key messages for interaction with students and plan of action for interactive discussions with students.

The curriculum and contents for MAT for journalists were also the same as MAT for schoolteachers however, the methodology for training on cough medicines and antibiotics were different for this group. The methodology included different group activities focused to identifying problems related to cough medicines and antibiotics use, developing key messages on cough medicines for communication through F.M. radio, developing key messages on antibiotics for communication through newspapers/ magazines, and plan of action for dissemination to the communities through different media.

\section{Training of school teachers and journalists}

The training of schoolteachers was held from January 810,2009 in Kathmandu and participated by 14 teachers from the sampled schools.

Similarly, MAT for journalists was held from January 1517, 2009 in Kathmandu and there were 19 participants from newspapers, T.V. channels, F.M. radios and magazines.

\section{Dissemination of key messages}

The key messages on vitamin/tonics were disseminated by schoolteachers' though interactive discussion with students (Table 1).

Similarly, the key messages on cough medicines were disseminated through Kantipur F.M. and Bhaktapur 
F.M. 6 times a day for 2 weeks. The messages were broadcasted before the news time (Table 2).

The key messages on antibiotics were published by the journalists in few local newspapers/ magazines (Table $3)$.

A member of study team supervised the interactive discussion of the teachers with the students of 6-9 grades of all the sampled schools.

\section{Data collection}

The baseline data from households was collected in December 2008. The post-intervention data were collected in March 2009, about 4 weeks after the completion of interventions.

Household interview included questions about the action of antibiotic, methods of administration for the use of antibiotics, consequence of incorrect use of antibiotics, sources of vitamins, use of vitamins/tonics in the family, usefulness of vitamin/tonics, cough as a disease and use of cough medicines in the family.

The baseline and post-intervention assessment data were collected by four research assistants. A member of the study team supervised the data collection from households in the baseline and post-intervention period.

\section{Outcome indicators and data analysis}

Data were entered into SPSS-15 database. Before entering the data, the households' responses were categorized and coded. Outcome indicators specified were- \% correct knowledge on action of antibiotics, $\%$ knowledge on methods of administration for the use of antibiotics, \% knowledge on the consequence of incorrect use of antibiotics, \% knowledge on cough as a disease, \%use of cough medicines in the last two weeks, \% knowledge on the usefulness of vitamin/ tonics, $\%$ knowledge on the sources of vitamins, $\%$ use of vitamin/tonics in the last two weeks.

The Chi-square test was applied to measure the change in pre-post comparison. The level of significant difference was measured at $95 \%$ confidence limit.
The knowledge on action of antibiotic was defined correct if during the interview the household could identify "effectiveness" against bacteria.

The knowledge on methods of administration for the use of antibiotics was considered "excellent" if during the interview the household could identify dose, frequency and duration of treatment.

The knowledge on consequences of the incorrect use of antibiotic was considered "good" if during the interview the household could identify bacterial resistance and harmful effect.

The knowledge on usefulness of vitamin/tonics was defined "correct" if during the interview the household could identify not useful in providing energy, increasing weight and increasing appetite.

The knowledge on sources of vitamins for the body was considered "excellent" if during the interview the household could identify diet, green vegetables and fruits.

The knowledge on cough as a disease was defined correct if during the interview the household could identify "it is not a disease".

Results

\section{Knowledge on antibiotics}

Table 4 shows that the effect of intervention was associated with a significant increase in correct knowledge on action of antibiotics and excellent knowledge on methods of administration of antibiotics.

Knowledge on cough and practice of cough medicines

Table 4 shows that the intervention was associated with significant increase in knowledge on cough as a disease. There was also a significant decrease in use of cough medicines.

Knowledge on vitamins and practice of vitamin/tonics The intervention was associated with a significant increase in excellent knowledge on source of vitamins, and use of vitamin/tonics was decreased significantly (Table 4). 
Table 1: Key messages on cough and cough medicines given to the communities

\begin{tabular}{|l|l|}
\hline Condition and treatment & \multicolumn{1}{c|}{ Messages } \\
\hline Cough & $\begin{array}{l}\text { Cough is not a disease, it is only the symptom of a disease. } \\
\text { It is a defensive mechanism of respiratory system and usually subsides without } \\
\text { treatment. } \\
\text { Infection, allergy and foreign body in the respiratory tract can produce cough. } \\
\text { It should be treated only after disease has been diagnosed. }\end{array}$ \\
\hline Cough Medicines & $\begin{array}{l}\text { Cough medicines should not be used merely for symptom. } \\
\text { Cough medicine to suppress the dry cough could create problems in making di- } \\
\text { agnosis. They should be used only after the diagnosis of a disease. } \\
\text { Cough medicines containing codeine is addictive. } \\
\text { The cough expectorants are not effective. Steam inhalation is effective than ex- } \\
\text { pectorants. }\end{array}$ \\
\hline Home remedies & $\begin{array}{l}\text { Home medicines like drinking hot water, water boiled with turmeric or vasaka or } \\
\text { ocimum are effective remedies against cough. }\end{array}$ \\
\hline
\end{tabular}

Table 2: Key messages on antibiotics given to the communities

\begin{tabular}{|l|l|}
\hline Condition and treatment & \multicolumn{1}{|c|}{ Messages } \\
\hline \multirow{7}{*}{ Infection } & $\begin{array}{l}\text { Infection can be caused by bacteria, virus, fungus and amoeba. } \\
\text { Antibiotics are effective against infections caused by bacteria only. They are not } \\
\text { effective against infections caused by other than bacteria. }\end{array}$ \\
\hline Antibiotics & $\begin{array}{l}\text { There are several antibiotics and the choice of an antibiotic should be based on } \\
\text { type of infection. } \\
\text { The antibiotic is not effective if not used on the basis of specific type of } \\
\text { infection. } \\
\text { The antibiotic may not be effective if it is not used in proper dose, frequency and } \\
\text { duration. } \\
\text { The antibiotic may be harmful if not used properly. } \\
\text { There is merely waste of money if antibiotic is not used properly. }\end{array}$ \\
\hline
\end{tabular}

Table 3: Key messages on vitamin/ tonics given to the communities

\begin{tabular}{|l|l|}
\hline Condition and treatment & \multicolumn{1}{c|}{ Messages } \\
\hline \multirow{3}{*}{ Vitamin and tonics } & Vitamin/tonics do not provide energy or increase weight. \\
& $\begin{array}{l}\text { Daily requirement of vitamins is in very small quantities and is met through } \\
\text { fruits, green vegetables and balanced diet. } \\
\text { Unnecessary use of vitamin/tonics causes financial burden. } \\
\\
\text { Vitamin tablets or capsules are cheaper and convenient to use than liquid prepa- } \\
\text { rations }\end{array}$ \\
\hline
\end{tabular}


Table 4: Indicators pre and post-implementation and impact of the intervention

\begin{tabular}{|l|c|c|c|}
\hline \multicolumn{1}{|c|}{ Indicator } & Pre (n=288) & Post (n=288) & p-value \\
\hline a) Antibiotics & & & 0.000 \\
\hline$\%$ correct knowledge on action & 14.2 & 30.6 & 0.000 \\
\hline $\begin{array}{l}\text { \% excellent knowledge on methods of } \\
\text { administration }\end{array}$ & 21.9 & $34.0^{*}$ & 0.000 \\
\hline$\%$ good knowledge on consequence of incorrect use & 12.5 & $26.0 *$ & 0.000 \\
\hline b) Cough and cough medicines & & & 0.000 \\
\hline$\%$ correct knowledge on cough as a disease & 19.8 & 37.5 & \\
\hline$\%$ use of cough medicines & 21.2 & 5.6 & 0.001 \\
\hline c) Vitamin/tonics & & & 47.6 \\
\hline$\%$ excellent knowledge on source of vitamins & 34.4 & 5.2 & 0.000 \\
\hline$\%$ use of vitamin/tonics & 13.9 & & \\
\hline$* \mathrm{n}=275$ & & & \\
\hline
\end{tabular}

\section{Discussion}

Various community studies in different countries have shown that a well-planned educational intervention can be effective in improving specific problem of drug use e.g. reducing use of injections, increasing adherence to antibiotics and other medicines, appropriate treatment of acute respiratory infections and improved use of medicine for malaria prophylaxis. The present intervention has been designed using schoolteachers, journalists and school children as intermediary groups for educating the community members. The schoolteachers who have been trained on different contents on medicine awareness developed and disseminated key messages to students. The key messages on vitamin/tonics were developed by the teachers during the training. An interactive discussion of the teacher with students of each grade on key messages was held. The students subsequently shared the key messages to their families, mostly mothers. However, the family members have not specified their children as source of information when they have been interviewed. Similarly, journalists have been trained on different contents with the main focus on improving use of antibiotics and cough medicines in the community using key messages. The key messages on cough and cough medicines were developed during the training for dissemination through F.M. radios. They also developed key messages on antibiotics for dissemination through newspapers/T.V. channels/ magazines. The key messages on the use of cough medicines have been disseminated through F.M. radio stations and the key messages on antibiotics have been covered in the local newspapers/ magazines.

For maintaining validity and reliability, the study team members have supervised all the steps/processes including development of instruments, field-testing of instruments, interactive discussion with students, households' data collection, completeness of the collected data, correctness of data entry, correctness of secondary coding and their entries.

The community knowledge on the use of antibiotics has improved. Similarly, the community knowledge on the sources of vitamins has also improved. There has also been a significant improvement in the use of vitamin/ tonics by the community members. Likewise, there has been an improvement in the community knowledge on cough as a disease. The community practice of cough medicines has also been improved.

\section{Conclusion}

The participation of intermediary groups eg. schoolteachers, journalists and school children in the implementation of intervention were successful. The groups have fulfilled the commitments in implementing the plan of action. The key messages have effectively reached the households, and the knowledge and practices of the community members in drug use have improved.

\section{Limitations}

a. only one month post-intervention effects have been measured

b. pre-post effects of intervention has not been measured in terms of gender, ethnicity, education and economic status.

\section{Acknowledgements}

We are thankful to WHO for funding the study. We also acknowledge the valuable support of Pharmaceutical Horizon of Nepal (PHON) for conducting MAT schoolteachers and journalists. 


\section{References}

1. WHO. The role of education in the rational use of medicines. Technical Report Series 45. New Delhi: SEARO; 2006.

2. Abosede OA. Self-medication an important aspect of health care. Soc Sci Med. 1984; 19: 699-703.

3. WHO. Self-medication and its impact on essential drug schemes in Nepal: socio-cultural research project. Technical Report Series. Geneva: WHO; 1993.

4. Igun UA. Why we seek treatment here-retail pharmacy and clinical practice in Maiduguri, Nigeria. Soc Sci Med. 1987; 24: 689-95

5. Kafle KK, Shrestha AD, Karkee SB, Das P, Pradhan YMS, Laing RO, et al. Safe dispensing and appropriate referral for diarrhea, ARI and pregnancy by retail drug sellers in Nepal. Nepal: INRUD; 1994.

6. Kafle KK, Shrestha AD, Karkee SB, Yadav BP, Prasad RR, Shrestha N, et al. Baseline assessment of consumer drug use. Nepal: USAID/RPM/JSI, INRUD; 1995.

7. Kafle KK, Bhuju GB, Shrestha BM, Humagain BR, D. C. GB, Rajbhandari V et al. Impact of an article on drug use in the community, Pharmaceutical Horizon of Nepal (PHON) Technical Report2003

8. Kafle KK, Bhuju GB, Shrestha BM, Humagain BR, D. C. GB, Rajbhandari V, et al. Evaluation of wall poster on use of antibiotics, PHON Technical Report. Nepal: Pharmaceutical Horizon of Nepal; 2000
9. Akici A, Kalaca S, Ugurlu MU, Toklu HZ, Iskender E, Oktay S. Patient knowledge about drugs prescribed at primary health care facilities. Pharmacoepidemiol Drug Saf. 2004; 13: 871-76.

10. Hubley J. Patient education in the developing world-a discipline comes of age. Patient Educ Couns. 2006; 61(1): 161-4.

11. Hadyiono PJE, Suryawati S, Danu SS, Sunartono, Santoso B. Interactional group discussions: results of a controlled trial using a behavioral intervention to reduce the use of injections in public health facilities. Soc Sci Med. 1996; 42: 1177-83.

12. Kidane G, Morrow RH. Teaching mothers to provide home treatment of malaria in Tigray, Ethiopia: a randomized trial. Technical Report. 2001.

13. Bratt DE. Training mothers in use of oral rehydration therapy. Technical Report. 2001.

14. Kafle KK, Humagain B, Thapa BB, Shrestha BM, Bhuju GB, DC GB et al. Medicine Awareness Training (MAT) for schoolteachers and women groups: an intervention study, PHON Technical Report. Nepal: Pharmaceutical Horizon of Nepal; 2001.

15. Holloway KA, Karkee SB, Tamang AL, Gurung YB, Kafle KK, Pradhan R, et al. Community intervention to promote rational treatment of acute respiratory infection in rural Nepal. Tropical Medicines and International Health. 2009; 14: 101-110. 